\title{
Physician Sign Off Indicator
}

National Cancer Institute

\section{Source}

National Cancer Institute. Physician Sign Off Indicator. NCI Thesaurus. Code C93623.

Specifies whether a doctor has reviewed and signed off on a document or activity. 